University of Nebraska - Lincoln

DigitalCommons@University of Nebraska - Lincoln

USGS Staff - Published Research

US Geological Survey

2008

Range-Wide Patterns of Greater Sage-Grouse Persistence

Cameron L. Aldridge

Natural Resource Ecology Laboratory, Colorado State University and US Geological Survey, 2150 Centre

Avenue, Building C, Fort Collins, CO 80526-8118, USA

Scott E. Nielsen

University of Alberta, Edmonton, Canada

Hawthorne L. Beyer

University of Alberta, Edmonton, Canada

Mark S. Boyce

University of Alberta, Edmonton, Canada

John W. Connelly

Idaho State University, Pocatello, ID 83209, USA

See next page for additional authors

Follow this and additional works at: https://digitalcommons.unl.edu/usgsstaffpub

Part of the Earth Sciences Commons

Aldridge, Cameron L.; Nielsen, Scott E.; Beyer, Hawthorne L.; Boyce, Mark S.; Connelly, John W.; Knick, Steven T.; and Schroeder, Michael A., "Range-Wide Patterns of Greater Sage-Grouse Persistence" (2008). USGS Staff -- Published Research. 42.

https://digitalcommons.unl.edu/usgsstaffpub/42

This Article is brought to you for free and open access by the US Geological Survey at DigitalCommons@University of Nebraska - Lincoln. It has been accepted for inclusion in USGS Staff -- Published Research by an authorized administrator of DigitalCommons@University of Nebraska - Lincoln. 


\section{Authors}

Cameron L. Aldridge, Scott E. Nielsen, Hawthorne L. Beyer, Mark S. Boyce, John W. Connelly, Steven T. Knick, and Michael A. Schroeder 


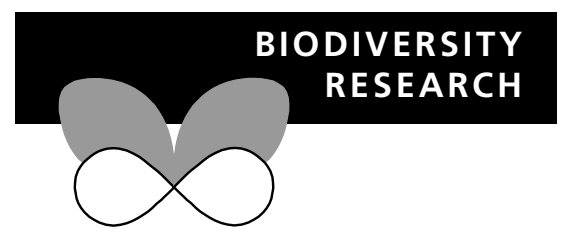

\title{
Range-wide patterns of greater sage-grouse persistence
}

\author{
Cameron L. Aldridge ${ }^{1 \star}$, Scott E. Nielsen ${ }^{2,6}$, Hawthorne L. Beyer, ${ }^{2,7}$ Mark S. \\ Boyce, ${ }^{2}$ John W. Connelly, ${ }^{3}$ Steven T. Knick ${ }^{4}$ and Michael A. Schroeder ${ }^{5}$
}

${ }^{1}$ Natural Resource Ecology Laboratory, Colorado State University and US Geological Survey, 2150 Centre Avenue, Building C, Fort Collins, $C O$ 80526-8118, USA, ${ }^{2}$ Department of Biological Sciences, University of Alberta, Edmonton, Canada AB T6G 2E9, ${ }^{3}$ Idaho Fish and Game, Department of Biological Sciences, Idaho State University, Pocatello, ID 83209, USA, ${ }^{4}$ Snake River Field Station, USGS Forest and Rangeland Ecosystem Science Center, 970 Lusk Street, Boise, ID 83706, USA, ${ }^{5}$ Washington Department of Fish and Wildlife, PO Box 1077, Bridgeport, WA 98813, USA, ${ }^{6}$ ASRC Management Services at USGS Fort Collins Science Center, Centre Avenue Building C, Fort Collins, CO 805268118, USA, ${ }^{7}$ Division of Environmental and Evolutionary Biology, University of Glasgow, Graham Kerr Building, Glasgow G12 8QQ

\footnotetext{
${ }^{*}$ Correspondence: Cameron L. Aldridge, Natural Resource Ecology Laboratory, Colorado State University and US Geological Survey, 2150 Centre Avenue, Building C, Fort Collins, CO 80526-8118, USA. Tel.: 970-226-9433; Fax: 970-226-9298;

E-mail: cameron_aldridge@usgs.gov
}

\begin{abstract}
Aim Greater sage-grouse (Centrocercus urophasianus), a shrub-steppe obligate species of western North America, currently occupies only half its historical range. Here we examine how broad-scale, long-term trends in landscape condition have affected range contraction.
\end{abstract}

Location Sagebrush biome of the western USA.

Methods Logistic regression was used to assess persistence and extirpation of greater sage-grouse range based on landscape conditions measured by human population (density and population change), vegetation (percentage of sagebrush habitat), roads (density of and distance to roads), agriculture (cropland, farmland and cattle density), climate (number of severe and extreme droughts) and range periphery. Model predictions were used to identify areas where future extirpations can be expected, while also explaining possible causes of past extirpations.

Results Greater sage-grouse persistence and extirpation were significantly related to sagebrush habitat, cultivated cropland, human population density in 1950, prevalence of severe droughts and historical range periphery. Extirpation of sagegrouse was most likely in areas having at least four persons per square kilometre in 1950, 25\% cultivated cropland in 2002 or the presence of three or more severe droughts per decade. In contrast, persistence of sage-grouse was expected when at least $30 \mathrm{~km}$ from historical range edge and in habitats containing at least $25 \%$ sagebrush cover within $30 \mathrm{~km}$. Extirpation was most often explained (35\%) by the combined effects of peripherality (within $30 \mathrm{~km}$ of range edge) and lack of sagebrush cover (less than $25 \%$ within $30 \mathrm{~km}$ ). Based on patterns of prior extirpation and model predictions, we predict that $29 \%$ of remaining range may be at risk.

Main Conclusions Spatial patterns in greater sage-grouse range contraction can be explained by widely available landscape variables that describe patterns of remaining sagebrush habitat and loss due to cultivation, climatic trends, human population growth and peripherality of populations. However, future range loss may relate less to historical mechanisms and more to recent changes in land use and habitat condition, including energy developments and invasions by non-native species such as cheatgrass (Bromus tectorum) and West Nile virus. In conjunction with local measures of population performance, landscape-scale predictions of future range loss may be useful for prioritizing management and protection. Our results suggest that initial conservation efforts should focus on maintaining large expanses of sagebrush habitat, enhancing quality of existing habitats, and increasing habitat connectivity.

\section{Keywords}

Centrocercus urophasianus, distribution, extirpation, greater sage-grouse, persistence, range contraction, sagebrush. 


\section{INTRODUCTION}

Sagebrush (Artemisia spp.) habitats have undergone significant change since the 1900s due to habitat loss, degradation and fragmentation (Knick et al., 2003; Connelly et al., 2004). Consequently, greater sage-grouse (Centrocercus urophasianus) currently occupies only about $56 \%$ of their historical presettlement range (Schroeder et al., 2004) with many monitored populations declining by approximately 2\% per year since 1965 (Connelly \& Braun, 1997; Braun, 1998; Connelly et al., 2004). Today, the quantity and quality of remaining sagebrush habitats are threatened by agricultural conversion (Connelly et al., 2004), invasion of habitats by exotic plants (Wisdom et al., 2002a; Knick et al., 2003; Connelly et al., 2004), disturbances from energy exploration and extraction (Braun et al., 2002; Lyon \& Anderson, 2003; Holloran et al., 2005), high grazing intensity (long duration and high stocking rates; Beck \& Mitchell 2000; Hayes \& Holl, 2003; Crawford et al., 2004), fire (Connelly et al., 2000, 2004) and climate change (Neilson et al., 2005).

While several assessments characterizing threats to sagebrush habitats (Knick et al., 2003; Connelly et al., 2004; Wisdom et al., 2005a; Rowland et al., 2006a) and more specifically to greater sage-grouse (Wisdom et al., 2002a,b; Connelly et al., 2004) have been conducted, only a few address greater sage-grouse population declines relative to landscape characteristics (Aldridge \& Boyce 2007; Walker et al., 2007). Ultimately, range-wide conservation of greater sage-grouse will require broad-scale characterization of habitat quality and an understanding of the influence of landscape condition on the persistence of populations. Despite possible protection of the species under the United States Endangered Species Act, no range-wide assessment has been conducted that relates range contraction to past and current landscape conditions.

A recent conservation assessment of greater sage-grouse and sagebrush habitats (Connelly et al., 2004) resulted in the compilation of data on sage-grouse distribution, population trends and habitats. As part of this effort, a digital map depicting the current and likely presettlement (c. 1800) distribution of greater sagegrouse was developed (Schroeder et al., 2004). We assessed the relationship between landscape conditions and range contraction based on current and presettlement distribution to identify possible drivers affecting greater sage-grouse range occupancy. Specifically, we developed a greater sage-grouse persistence model contrasting the current and estimated presettlement distribution for greater sage-grouse as a function of landscape variables using logistic regression and a geographic information system (GIS). To understand the influence of environmental and anthropogenic factors on greater sage-grouse persistence, we estimated doseresponse curves for model variables and identified possible threshold values for persistence. We hypothesized that sage-grouse are least likely to persist near their historical range periphery or in areas with high levels of agricultural development, road density, human population or frequent droughts, and we expected that persistence is positively related to amount of sagebrush habitat. Based on past patterns in greater sage-grouse distribution and estimated threshold values, we applied our model to the current distribution of greater sage-grouse to investigate causes of historical declines and to the extant distribution of greater sage-grouse to identify populations most likely to persist and those where management actions would be most beneficial.

\section{METHODS}

\section{Quantifying range persistence}

We used digital maps of estimated presettlement (historical) and current (2004) range to delineate the historical and current distribution of greater sage-grouse (hereafter sage-grouse) in North America (Schroeder et al., 2004; see Fig. 1). Current distribution was based on numerous sources, including counts of males at display sites, survey routes, harvest information and radiotelemetry research (Schroeder et al., 2004). Historical distribution, on the other hand, was estimated from 1167 museum specimens, 138 published records, records from historical publications and journals and the presettlement distribution of potential habitat (see Schroeder et al., 2004 for details). Across the identified historical sage-grouse range, sample locations were systematically generated $(n=41,802)$ in a GIS at $5-\mathrm{km}$ spacing, representing the mean distance between all known sage-grouse leks (5654 active and inactive leks; Connelly et al., 2004). Locations that occurred within currently occupied range $(n=24,762)$ were classified as persistent (1), while locations within extirpated range $(n=17,045)$ were classified as extirpated $(0)$.

\section{Landscape predictors of persistence}

Landscape variables used to predict the status (persistence or extirpation) of sage-grouse were divided into six broad categories. These included human population (density and population change), vegetation (percentage of sagebrush habitat), roads (density of and distance to roads), agriculture (cropland, farmland and cattle density), climate (number of severe and extreme droughts) and a measure of peripherality (distance to historical sage-grouse range edge; see Table 1). We obtained estimates of human population density in 1900, 1950 and present (c. 2000), as well as human population change from 1900 and 1950-2000, from the 2000 United States Census Bureau to assess human encroachment into sage-grouse habitats (Table 1). Human population in 1900 was chosen to represent density prior to intense European settlement, and the density in 1950 approximated the period when earliest recorded demographic declines (lek counts) in sage-grouse populations occurred (1965; Connelly et al., 2004). We used the Comer et al. (2002) landcover classification that was reclassified by Connelly et al. (2004) to emphasize the distribution of sagebrush habitats, which combined 10 major sagebrush species into a single sagebrush cover class. The original $90-\mathrm{m}$ pixel map produced by Comer et al. (2002) was developed by cross-walking readily available regional data sets on vegetation, elevation and soil characteristics, which included 30- to 90-m pixel raster layers and 1:24000 and 1:100 000 scale polygon coverages. Silver sagebrush, Artemisia cana, which occurs in the north-eastern part of sage-grouse range, was not included in this 


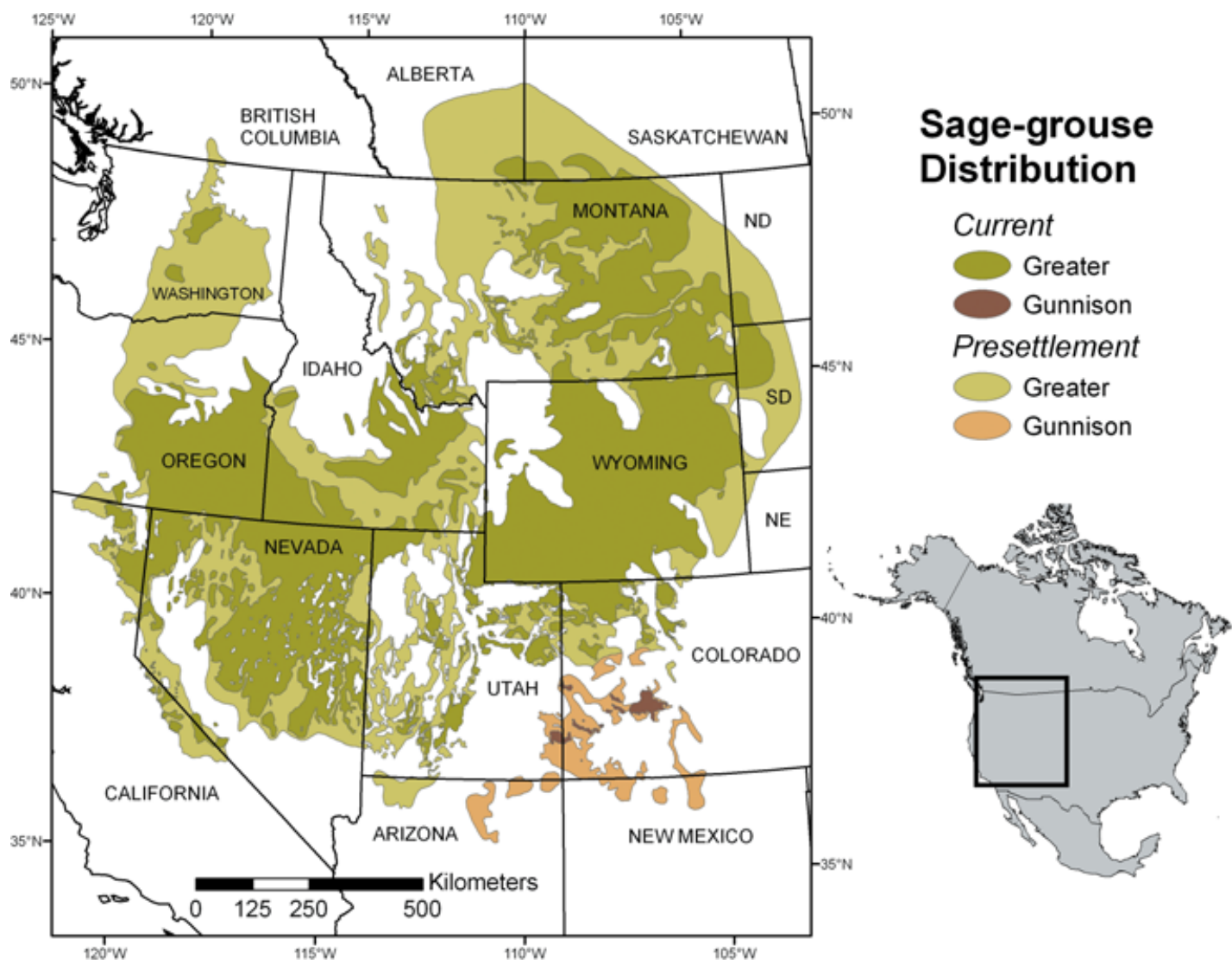

Figure 1 Current and potential presettlement distribution of both greater sage-grouse (Centrocercus urophasianus) and Gunnison sage-grouse (Centrocercus minimus) in North America. Adapted from Schroeder et al. (2004) with permission. Our analyses focused on greater sage-grouse only. Map projection is Albers Equal Area; Datum is North American Datum 1983.

classification, limiting the applicability to that portion of the range. Similar data for sagebrush were not available for the Canadian range of sage-grouse $(<1 \%$ of current species range; Aldridge \& Brigham 2003; Schroeder et al., 2004), precluding assessment of persistence in Canada.

We summarized percentage of sagebrush habitat (90-m pixel base layer) for two scales of extent across the entire landscape: (1) a radius of $1 \mathrm{~km}$ and (2) a radius of $30.77 \mathrm{~km}$. The $1-\mathrm{km}$ window represents the scale of a local habitat patch, and the larger window represents the known upper limit for an annual sage-grouse home range ( $2975 \mathrm{~km}^{2}$; Connelly et al., 2000, 2004). Computational limits required that percentage of sagebrush habitat in the $30.77-\mathrm{km}$ radius be estimated for $1-\mathrm{km}^{2}$ pixels, while percentage of sagebrush within a $1-\mathrm{km}$ radius was summarized at the original 90-m sagebrush habitat pixel (i.e. $8100 \mathrm{~m}^{2}$ ). We estimated the current density of all mapped roads (linear kilometre per square kilometre, Table 1) within $30.77 \mathrm{~km}$ for each $1-\mathrm{km}^{2}$ pixel used for percentage of sagebrush habitat. We used the information from the 2002 United States Census of Agriculture to estimate livestock density (number per square kilometre) and percentage of cultivated cropland or farmland per county (Table 1). Information was gathered from the National Climate Data Center (see Table 1) to estimate prevalence of severe or extreme droughts (Palmer Drought Index) between 1900 and 2003 or 1950 and
2003. Agricultural and human census data were at the resolution of counties, while the prevalence of severe and extreme droughts (Palmer Drought Indices) was measured at the scale of state climatic zones (Table 1). All other metrics were summarized over a $1-\mathrm{km}^{2}$ resolution (Table 1 ).

We calculated the distance to the edge of historical sage-grouse range as a measure of peripherality. For peripherality measures, we did not consider patches of non-habitat that were smaller than the upper size of a sage-grouse annual home range (i.e. $30.77 \mathrm{~km}$ radius or $2975 \mathrm{~km}^{2}$ ). For example, small 'islands' of mountainous terrain in Nevada that were not classified as historical sage-grouse range (Schroeder et al., 2004) and were $<30.77 \mathrm{~km}$ in radius were not considered as edges, whereas larger patches of non-range were considered as edges in estimates of peripherality.

\section{Persistence-extirpation model development}

We used logistic regression (Hosmer \& Lemeshow, 2000) to contrast locations where sage-grouse continue to persist (1) with locations where sage-grouse have been extirpated (0). HuberWhite sandwich estimators were used to account for correlation among samples within counties (census data), resulting in robust standard error estimates for coefficients (White, 1982). This minimized type I errors common to autocorrelated and 
Table 1 Summary of geographic information system predictor variables used for greater sage-grouse extirpation modelling. Variables with an asterisk $\left({ }^{*}\right)$ were uncorrelated and used in the preliminary multivariate model. Variables in bold were retained in the final model and used for predictions.

\begin{tabular}{|c|c|c|c|c|}
\hline Variable category & Variable name & Description & Grain of data output & Data source \\
\hline Human population metrics & $\begin{array}{l}\text { pop1900 } \\
{ }^{*} \text { pop1950 } \\
\text { pop2000 } \\
\text { popch1900 } \\
\text { popch1950 }\end{array}$ & $\begin{array}{l}\left.\text { Population density (people per } \mathrm{km}^{2}\right) \text { in } 1900 \\
\text { Population density }\left(\text { people per } \mathbf{k m}^{2}\right) \text { in } 1950 \\
\left.\text { Population density (people per } \mathrm{km}^{2}\right) \text { in } 2000 \\
\text { Change in human population }(1900-2000) \\
\text { Change in human population }(1950-2000)\end{array}$ & $\begin{array}{l}\text { County-level data } \\
(n=230)\end{array}$ & †US Census Bureau (2000) \\
\hline Agriculture & $\begin{array}{l}{ }^{*} \text { crop } \% \\
\text { farm } \%\end{array}$ & $\begin{array}{l}\text { Percentage of cropland in } \mathbf{2 0 0 2} \\
\text { Percentage of farmland (agricultural land used for crops, pasture or } \\
\text { grazing) in } 2002\end{array}$ & $\begin{array}{l}\text { County-level data } \\
(n=230)\end{array}$ & $\begin{array}{l}\text { ¥US Department of Agriculture National } \\
\text { Agricultural Statistics Service }-2002 \\
\text { Census of Agriculture }\end{array}$ \\
\hline Peripherality & $\begin{array}{l}{ }^{*} \text { cows } \\
{ }^{*} \text { km_edge }\end{array}$ & $\begin{array}{l}\text { Number of cows per } \mathrm{km}^{2} \text { in } 2002 \\
\text { Straight line distance }(\mathbf{k m}) \text { to historical outer edge of greater sage- } \\
\text { grouse range }\end{array}$ & 1-km pixel & Spatial Analyst Extension in ArcMap 8.2 \\
\hline Road metrics & $\begin{array}{l}{ }^{*} \text { roads } \\
\text { dtr_l } 1 \mathrm{~km}\end{array}$ & $\begin{array}{l}\text { Linear } \mathrm{km} \text { per } \mathrm{km}^{2} \text { of road } \\
\text { Distance to nearest road }-\mathrm{a} 1 \mathrm{~km} \text { derivative of NORM ED }\end{array}$ & $\begin{array}{l}1-\mathrm{km} \text { pixel } \\
1-\mathrm{km} \text { pixel }\end{array}$ & $\begin{array}{l}\text { \$US Department of Transportation } \\
\text { 930-m resolution of National Overview } \\
\text { Road Metrics Euclidean Distance }\end{array}$ \\
\hline Drought metrics & $\begin{array}{l}\operatorname{sev} 1900 \\
{ }^{*} \operatorname{sev} 1950 \\
\text { ext1900 } \\
\text { ext1950 }\end{array}$ & $\begin{array}{l}\text { Number of severe droughts (Palmer Index, } 1900 \text { to 2003) } \\
\text { Number of severe droughts (Palmer Index, } 1950 \text { to 2003) } \\
\text { Number of extreme droughts (Palmer Index, } 1900 \text { to 2003) } \\
\text { Number of extreme droughts (Palmer Index, } 1950 \text { to 2003) }\end{array}$ & $\begin{array}{l}\text { State climate zones } \\
(n=59)\end{array}$ & ${ }^{* *}$ National Climate Data Center \\
\hline Sagebrush habitat metrics & $\begin{array}{l}{ }^{*} \mathbf{s b} \% \_30 \\
\mathrm{sb} \% 1\end{array}$ & $\begin{array}{l}\text { Percentage of sagebrush habitat }(90-\mathrm{m} \text { pixels) within a } 30.77 \mathrm{~km} \text { radius } \\
\text { Percentage of sagebrush habitat (90-m pixels) within a } 1 \mathrm{~km} \text { radius }\end{array}$ & $\begin{array}{l}\text { 1-km pixel } \\
\text { 90-m pixel }\end{array}$ & $\begin{array}{l}\text { ††Comer et al. (2002) current } \\
\text { distribution of sagebrush (90-m pixel) }\end{array}$ \\
\hline
\end{tabular}

†URL: http://nationalatlas.gov/atlasftp.html; †URL: http://nationalatlas.gov/atlasftp.html?openChapters = chpagri\#chpagri; §URL: http://www.bts.gov/gis; 9 URL: http://www.fort.usgs.gov/products/publications/ 21426/21426.pdf; ${ }^{*}$ URL: http://www.ncdc.noaa.gov/oa/climate/onlineprod/drought/xmgr.html; ††URL: http://sagemap.wr.usgs.gov/images/sagel.jpg. 
pseudoreplicated data and ensured that inferences about coefficients were correct (Lennon, 2000; Diniz et al., 2003). We first conducted univariate analyses for each of the 17 candidate variables (Hosmer \& Lemeshow, 2000), using $P<0.25$ as a cut-off for potential inclusion in a final multivariable model based on a Wald $z$ statistic. We assessed each variable for outliers and non-linearities, as well as colinearities among variables (Hosmer \& Lemeshow, 2000). If two variables were correlated $(|r|>0.7)$, we retained only the variable that explained the greatest deviance and was most biologically meaningful. We fit a global multivariable model using these meaningful (in univariate analyses) and uncorrelated variables and sequentially dropped the least significant variable until all remaining variables were significant at $\alpha=0.10$ (Hosmer \& Lemeshow, 2000). We tested for potential interactions between covariates that were biologically meaningful, while also adding each previously removed variable from the global multivariate model to identify possible confounding variables (Hosmer \& Lemeshow, 2000). Finally, we used variance inflation factors (VIF; Menard, 1995) to test for any remaining multicollinearity between covariates in the final model. Multicollinearity was considered to be a problem if VIF scores for individual covariates were $>10$ or if a mean score was considerably greater than 1 (Chatterjee et al., 2000). All analyses were conducted in STATA version 8.2 (Stata Corporation, College Station, TX, USA).

\section{Model assessment}

We used a $\chi^{2}$ statistic to assess model fit (Hosmer \& Lemeshow, 2000) and receiver operating characteristic (ROC) curves to estimate predictive accuracy (Fielding \& Bell, 1997). ROC values above 0.9 were considered to have high model accuracy, 0.7-0.9 good model accuracy and $<0.7$ low model accuracy (Swets, 1988; Manel et al., 2001). We identified the optimal classification for the final model by minimizing the absolute value of the difference between sensitivity and specificity curves (Liu et al., 2005). We estimated the model's overall predictive classification accuracy at the identified optimal cut-off probability using percentage correctly classified (PCC). We considered PCC scores of $\geq 80 \%$ to have excellent model prediction, and $\geq 70 \%$ as reasonable prediction (Nielsen et al., 2004; Aldridge \& Boyce, 2007).

\section{Predictions of persistence or extirpation}

We used dose-response curves to describe relationships between model variables and sage-grouse status. To estimate doseresponse relationships for each factor, all variables except the one of interest were held at their mean with the probability of persistence predicted for the variable of interest across the range of values observed in the analysis. Predictions were plotted for each variable, and the threshold value of that variable at which persistence or extirpation occurred was estimated using the optimal cut-off probability for the model. Specifically, sage-grouse were predicted to persist when probability of persistence equalled or exceeded the optimal cut-off probability for that variable value, while probabilities of persistence below this threshold were predicted to be extirpated. We used a GIS to spatially predict the status of sage-grouse across the historical distribution within the USA. Based on the predicted values and the initial representation of current and historical sage-grouse range, we generated a confusion matrix (correct and incorrect classification of presences and absences) in the GIS to highlight areas of sage-grouse range considered to be secure and those most at risk. Specifically, we identified those areas where future extirpations could be expected based on the similarity of landscape conditions that resulted in previous extirpations. Spatial autocorrelation of model residuals were assessed using Moran's I correlelogram similar to Diniz et al. (2003) to ensure that spatial structure among counties did not confound model predictions.

\section{RESULTS}

Based on univariate analyses, we considered seven uncorrelated variables (Table 1) for inclusion in our global multivariable model of sage-grouse persistence. Two variables, cattle density (cows) and road density (road), were non-significant and sequentially removed, resulting in five predictors of sage-grouse range persistence. None of the remaining candidate variables had confounding effects when added back into the model, and no interactions among the remaining five variables were significant.

Sage-grouse range persistence was best predicted by human population density in 1950, percentage of cultivated cropland in the county, distance $(\mathrm{km})$ to historical range edge (peripherality), prevalence of severe droughts since 1950 and percentage sagebrush within $30.77 \mathrm{~km}$ (Table 2). Sage-grouse range was predicted to be lost in areas having higher human population density in $1950\left(\beta_{\text {pop } 1950}=-0.1855\right)$, in areas having undergone conversion to cultivated crops (c. 2002) $\left(\beta_{\text {crop } \%}=-0.0377\right)$ and where the prevalence of severe droughts since 1950 was greater $\left(\beta_{\text {sev1950 }}=-0.0579\right.$; Table 2). Specifically, there was a $16.9 \%$ decrease in sage-grouse persistence for every unit increase in human population density per square kilometre in 1950, a 3.7\% decrease in sage-grouse persistence per $1 \%$ increase in the percentage of cultivated cropland in 2000 and a 5.6\% decrease in sage-grouse persistence per additional severe drought since 1950 (Table 2; Fig. 2). Conversely, populations were more likely to persist in interior habitats (i.e. farther from the historical species range

Table 2 Estimated coefficients $\left(\beta_{i}\right)$, standard errors (SE), $P$-values (Wald $z$ statistic), percentage change in odds ratio per unit increase in covariate $\mathrm{X}(\%)$, percentage change in odds ratio for a standard deviation increase in covariate $\mathrm{X}(\% \mathrm{StdX})$, and standard deviation of $\mathrm{X}$ (SDofX) for the persistence of greater sage-grouse.

\begin{tabular}{lrlrrrr}
\hline Variable & \multicolumn{1}{l}{$\beta$} & SE & \multicolumn{1}{l}{ \% } & \multicolumn{1}{c}{$\%$} & \%StdX & SDofX \\
\hline pop1950 & -0.186 & 0.059 & 0.002 & -16.9 & -64.7 & 5.6 \\
crop\% & -0.038 & 0.009 & $<0.001$ & -3.7 & -45.3 & 16.0 \\
km_edge & 0.019 & 0.003 & $<0.001$ & 1.9 & 135.9 & 46.1 \\
sev1950 & -0.058 & 0.032 & 0.067 & -5.6 & -20.5 & 4.0 \\
sb\%_30 & 0.049 & 0.005 & $<0.001$ & 5.0 & 257.4 & 26.0 \\
\hline
\end{tabular}




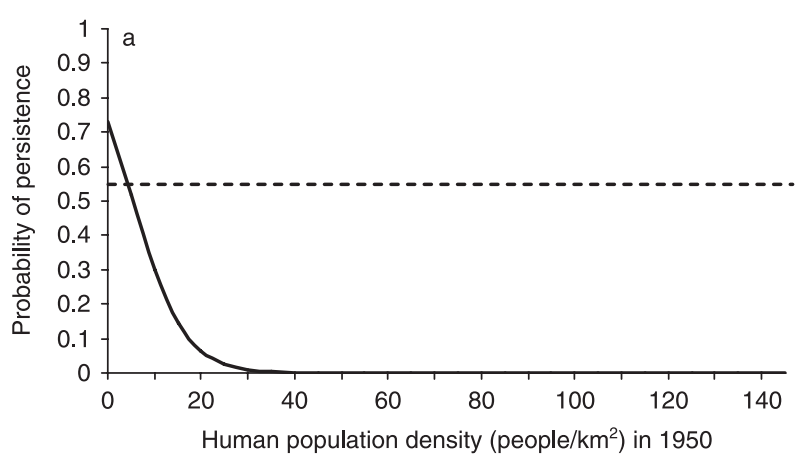

edge; $\left.\beta_{\text {km_edge }}=0.0186\right)$, and in habitats containing a greater proportion of sagebrush within $30.77 \mathrm{~km}\left(\beta_{\mathrm{sb} \% \_30}=4.8988\right)$. Overall, there was a $1.9 \%$ increase in the persistence of sage-grouse per $1 \mathrm{~km}$ increase in distance from the peripheral edge of historical range and a $5.0 \%$ increase in persistence of sage-grouse per $1 \%$ increase in the percentage of sagebrush habitat within $30.77 \mathrm{~km}$ (Table 2; Fig. 2). Given the observed variation in model variables, a one standard deviation change in percentage of sagebrush habitat resulted in the largest change $(257 \%)$ in sage-grouse persistence, followed by peripherality (136\%), human density in 1950 (65\%), percent cropland (45\%) and finally the prevalence of severe droughts between 1950 and 2003 (21\%) (Table 2). The effect of these changes on persistence (i.e. increase or decrease) depends on the sign of the coefficient, and the direction of change in the variable of interest. For instance, increasing sagebrush habitat by one standard deviation would increase sage-grouse persistence by $257 \%$, while increasing human density would decrease persistence by $65 \%$. Overall, our model of sage-grouse persistence had good fit (Wald $\chi_{5}^{2}=176.30, P<0.0001$ ) and predictive accuracy (ROC $=0.87$ ), and it explained $34.0 \%$ of the model variation.

We estimated the optimal model classification cut-off probability to be 0.5524 using the minimum absolute difference between sensitivity and specificity values. Above this cut-off probability, we predicted sage-grouse populations to persist, whereas below this probability, populations were predicted to be extirpated. Based on our predicted classification of sage-grouse range and the original digital map estimates of historical and current range, we estimated that the model had reasonable predictive capacity at an overall PCC value of 78.1\%. Using doseresponse curves, we estimated that sage-grouse were extirpated from areas of their range when human population densities exceeded four people per square kilometre in 1950, more than $25 \%$ of current habitat was in cultivated cropland, and if more than three of every 10 years between 1950 and 2003 were in severe drought condition (Fig. 2). Populations were predicted to persist if they were $>30 \mathrm{~km}$ from the edge of the historical range (less peripheral) and where $>25 \%$ of landscape within a $30.77-\mathrm{km}$ radius was dominated by sagebrush habitat (Fig. 2).

We applied our sage-grouse persistence model in a GIS to estimate predicted probabilities of persistence for the entire range of sage-grouse (Fig. 3). Comparing model predictions (persistenceextirpation) to the current range status in a confusion matrix, we found that $29 \%$ of sage-grouse range was composed of false negative classifications where sage-grouse currently persists, but

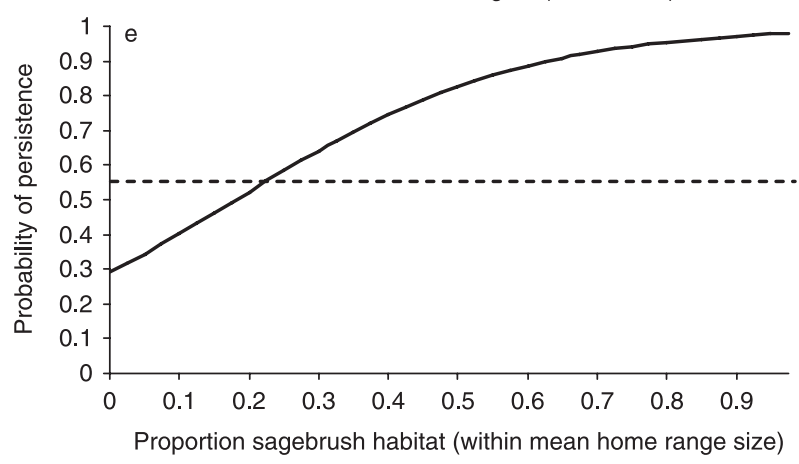

Figure 2 Threshold response curves for persistence of greater sage-grouse in North America. Dashed lines indicate optimal threshold cut-off probability $(0.5524)$ for each parameter while holding other model parameters at their mean value. Persistence (1) is predicted above the threshold, and extirpation (0) is predicted below the threshold. Responses are shown for all variables in the final model; (a) 1950 human population density, (b) area of cropland, (c) peripherality, (d) severe droughts (1950-2003) and (e) proportion of sagebrush habitat. 


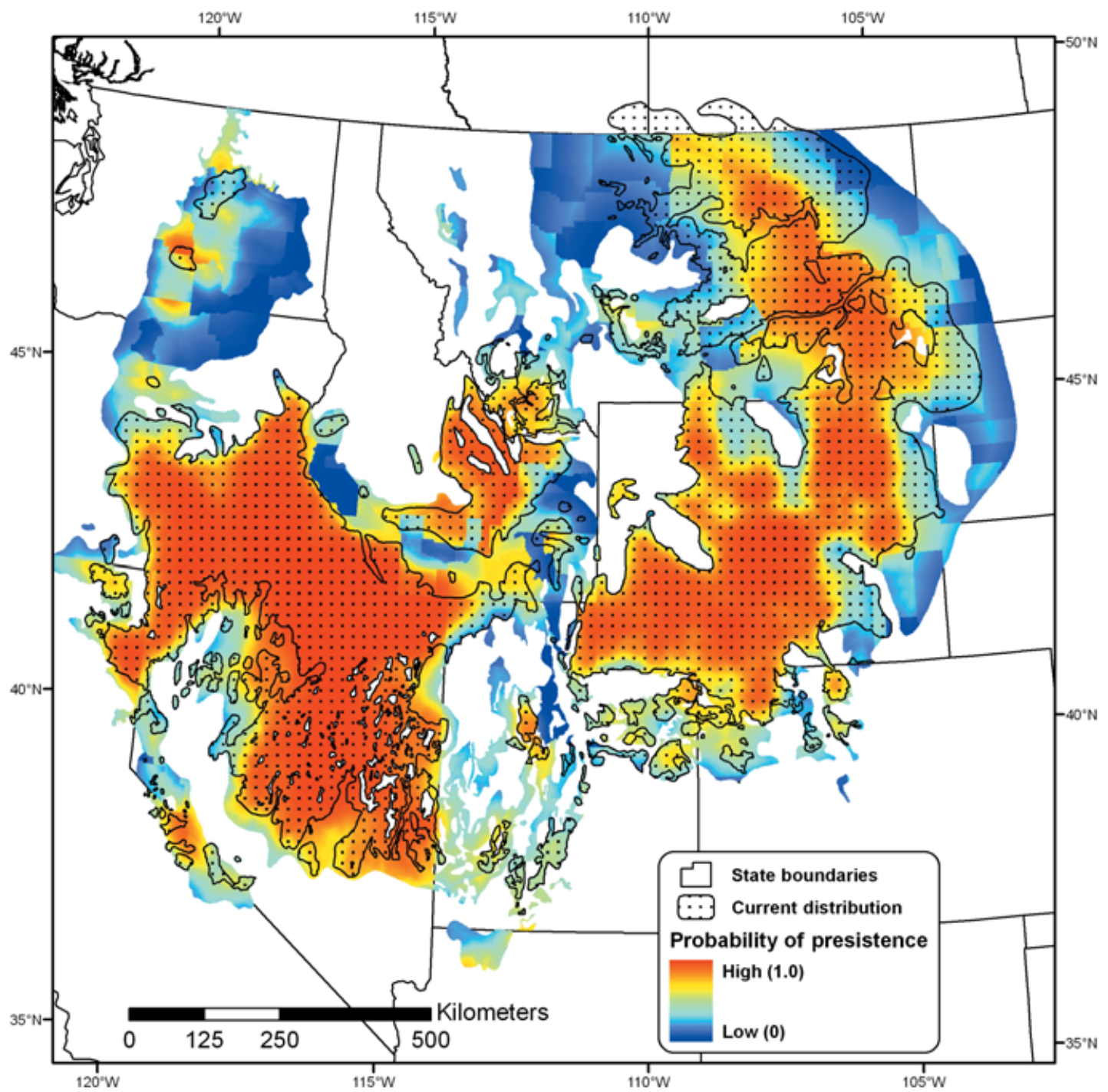

Figure 3 Predicted probability of persistence for greater sage-grouse throughout their historical distribution within the USA. Current distribution is overlaid (stippling). Similar data inputs were not available for Canada, so model development and predictions were restricted to the range of sage-grouse within the USA. Map projection is Albers Equal Area, Datum is North American Datum 1983.

based on landscape conditions where extirpations have occurred, these extant populations were predicted to be extirpated (Fig. 4). In contrast, false positive locations totalled $16 \%$ of sage-grouse range and identified areas where sage-grouse was predicted to be present, but is known to have been extirpated (Fig. 4). Moran's I correlelograms at $100 \mathrm{~km}$ lag distances indicated that little additional spatial structure (autocorrelation) remained among counties based on model predictions using the final model structure (Moran's I < 0.0355).

When spatial patterns of declines in sage-grouse range are examined using variable thresholds, sagebrush alone was responsible for $8.2 \%$ of those extirpations (Table 3). Edge alone resulted in $4.5 \%$ of extirpations, cropland $2.3 \%$, human population $1 \%$ and severe droughts $<1 \%$ of extirpations (Table 3 ). However, most extirpations resulted from cumulative effects of multiple landscape factors. For instance, sagebrush (or lack thereof), in combination with any other driver of extirpation resulted in $85.6 \%$ of extirpations (Table 3 ), with sagebrush habitat in combination with peripherality and cropland resulting in $66.3 \%$ of extirpations (top four ranked causes, Table 3).

\section{DISCUSSION}

Sage-grouse are a sagebrush obligate species (Braun et al., 1976; Paige \& Ritter, 1999; Schroeder et al., 1999; Connelly et al., 2004), with population declines associated with loss of sagebrush habitats (Swenson et al., 1987; Knick et al., 2003; Connelly et al., 2004; Schroeder et al., 2004). Maintenance of remaining sagebrush habitat therefore is paramount to the conservation and management of sage-grouse populations. To date, few suggestions have been made on critical levels of sagebrush habitat necessary to sustain sage-grouse populations. Using coarse-resolution maps 


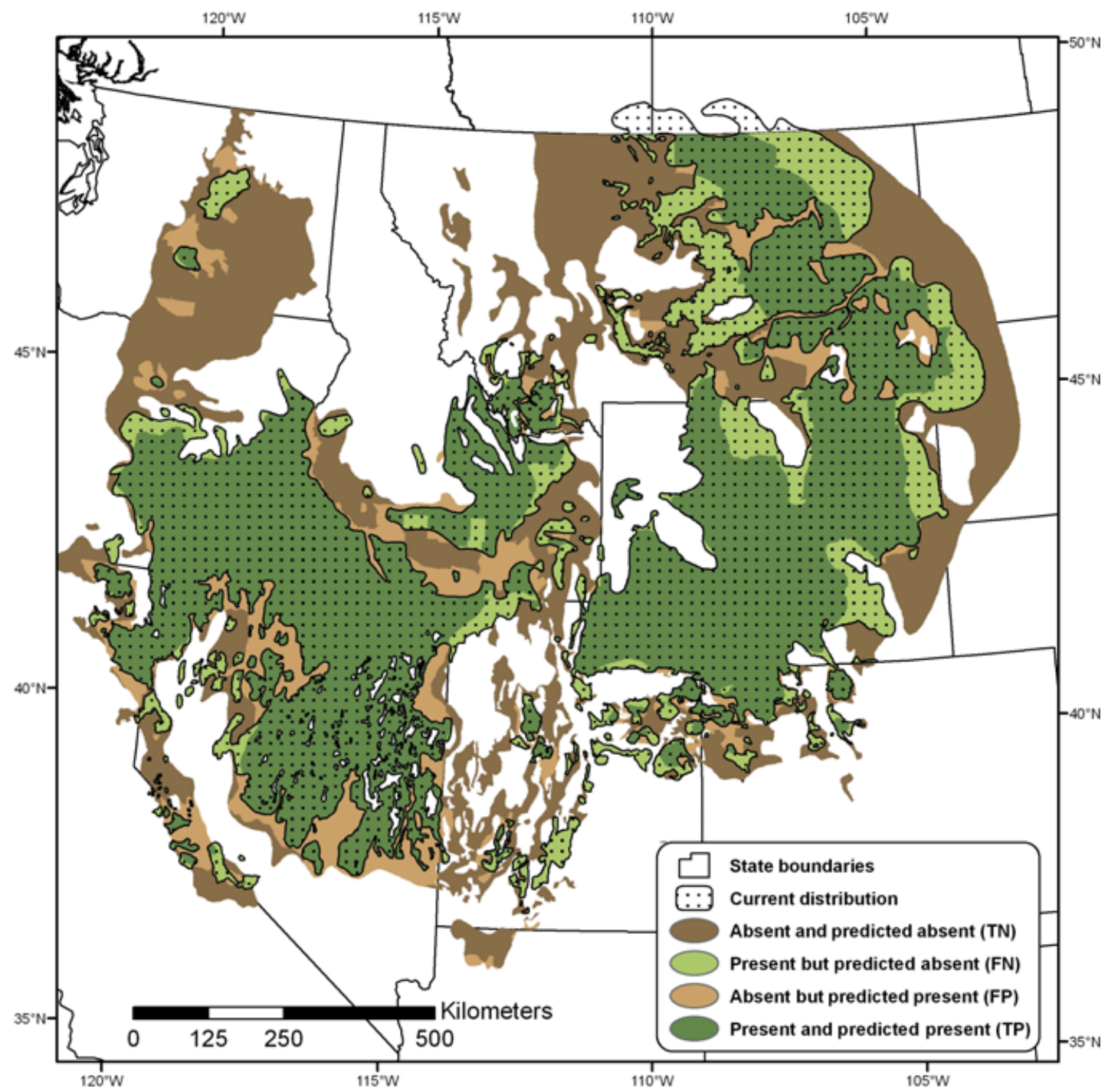

Figure 4 Predicted changes to greater sage-grouse distribution throughout North America. True positive (TP) indicates model correctly predicted greater sage-grouse persistence; true negative $(\mathrm{TN})$ is correct prediction of extirpation; false positive (FP) is predicted persistence where populations are known to be extirpated; false negative (FN) is predicted extirpation where populations are known to still persist. Map projection is Albers Equal Area, Datum is North American Datum 1983.

of sagebrush, we found long-term sage-grouse persistence required at least $25 \%$ sagebrush and preferably $65 \%$ sagebrush (to ensure high probability $(>0.9)$ ) within a $30.77-\mathrm{km}$ radius $\left(2975 \mathrm{~km}^{2}\right)$ scale. Further improvements in sagebrush mapping, particularly with reference to sagebrush cover and height by species, may improve estimates of critical levels of sagebrush habitat and quality necessary for sage-grouse persistence. Current sagebrush maps (i.e. Comer et al., 2002) do not include silver sagebrush, which is the dominant species in the north-east portion of sage-grouse range. As a consequence, accuracy of model predictions in persistence of sage-grouse for north-eastern Montana and the western Dakotas were limited (Fig. 4). Improvements in mapping of silver sagebrush would therefore enhance prediction in these regions. Regardless, given a year-round dependence of sage-grouse on sagebrush (Schroeder et al., 1999; Connelly et al., 2004; Hagen et al., 2007), maintaining large areas of intact sagebrush is critical to ensuring the long-term persistence of sage-grouse populations. Maintenance of large areas of sagebrush necessary for sage-grouse persistence may also act as an umbrella (Rowland et al., 2006b) for other sagebrush obligate species having smaller area requirements.

We did not find any relationship with livestock density in 2002. However, livestock numbers do not necessarily correlate with range condition, given that intensity, duration, and distribution ultimately affect rangeland health (Holechek et al., 2001). Further examination of historical and current effects of livestock grazing on sage-grouse persistence is needed (Connelly et al., 2000; Crawford et al., 2004). Conversely, sage-grouse extirpations were more likely to occur in areas where cultivated crops exceeded 25\% (Fig. 2b). Although sage-grouse are known to forage on agricultural crops, such as alfalfa (Patterson, 1952), extensive cultivation and fragmentation of native habitats 
Table 3 Predicted causes of greater sage-grouse extirpation based on thresholds of extirpation at sites where model predictions (extirpation) agreed with mapped extirpation of historical range (e.g. only TN - true negative sites in Fig. 4).

\begin{tabular}{|c|c|c|c|c|c|c|c|}
\hline \multirow[b]{2}{*}{ Area rank } & \multicolumn{5}{|c|}{ Landscape factors predicting extirpation } & \multirow{2}{*}{$\begin{array}{l}\text { Extirpated } \\
\text { range }(\%)\end{array}$} & \multirow[b]{2}{*}{ Description of predicted cause(s) of extirpation } \\
\hline & sb\%_30 & pop1950 & crop\% & sev1950 & km_edge & & \\
\hline 1 & $\downarrow$ & & & & $\downarrow$ & 34.5 & $\downarrow$ sagebrush and $\downarrow$ km edge \\
\hline 2 & $\downarrow$ & & $\uparrow$ & & & 15.7 & $\downarrow$ sagebrush and $\uparrow$ crop \\
\hline 3 & $\downarrow$ & & & & & 8.2 & $\downarrow$ sagebrush \\
\hline 4 & $\downarrow$ & & $\uparrow$ & & $\downarrow$ & 7.9 & $\downarrow$ sagebrush, $\uparrow$ crop and $\downarrow$ km edge \\
\hline 5 & $\downarrow$ & $\uparrow$ & $\uparrow$ & & & 5.1 & $\downarrow$ sagebrush, $\uparrow$ humans and $\uparrow$ crop \\
\hline 6 & & & & & $\downarrow$ & 4.5 & $\uparrow$ edge \\
\hline 7 & $\downarrow$ & $\uparrow$ & & & $\downarrow$ & 4.2 & $\downarrow$ sagebrush, $\uparrow$ humans and $\downarrow$ km edge \\
\hline 8 & $\downarrow$ & $\uparrow$ & $\uparrow$ & & $\downarrow$ & 4.1 & $\downarrow$ sagebrush, $\uparrow$ humans, $\uparrow \mathrm{km}$ edge and $\uparrow$ crop \\
\hline 9 & $\downarrow$ & & & $\uparrow$ & $\downarrow$ & 4.0 & $\downarrow$ sagebrush, $\uparrow$ severe droughts and $\downarrow$ km edge \\
\hline 10 & & $\uparrow$ & $\uparrow$ & & & 2.4 & $\uparrow$ humans and $\uparrow$ crop \\
\hline 11 & & & $\uparrow$ & & & 2.3 & $\uparrow$ crop \\
\hline 12 & & & & $\uparrow$ & $\downarrow$ & 2.0 & $\uparrow$ severe droughts and $\downarrow$ km edge \\
\hline 13 & $\downarrow$ & $\uparrow$ & & & & 1.6 & $\downarrow$ sagebrush and $\uparrow$ humans \\
\hline 14 & & & $\uparrow$ & & $\downarrow$ & 1.1 & $\uparrow \mathrm{km}$ edge and $\uparrow$ crop \\
\hline 15 & & $\uparrow$ & & & $\downarrow$ & 1.1 & $\uparrow$ humans and $\downarrow$ km edge \\
\hline 16 & & $\uparrow$ & & & & 1.0 & $\uparrow$ humans \\
\hline 17 & $\downarrow$ & & & $\uparrow$ & & 0.26 & $\downarrow$ sagebrush and $\uparrow$ severe droughts \\
\hline 18 & & & & $\uparrow$ & & 0.10 & $\uparrow$ severe droughts \\
\hline 19 & & $\uparrow$ & $\uparrow$ & & $\downarrow$ & 0.04 & $\uparrow$ humans, $\uparrow$ crop and $\downarrow$ km edge \\
\hline
\end{tabular}

Note: $\mathrm{sb} \% \_30$ is the percentage of sagebrush habitat (90 m pixels) within a 30.77-km radius.

pop1950 is the population density (people per $\mathrm{km}^{2}$ ) in 1950.

crop\% is the percentage of cropland in 1997.

sev1950 is the number of severe droughts (Palmer Index, 1950 to 2003).

$\mathrm{km} \_$edge is the straight line distance $(\mathrm{km})$ to historic outer edge of greater sage-grouse range.

have been associated with sage-grouse population declines (Schroeder, 1997; Braun, 1998; Leonard et al., 2000; Aldridge \& Brigham, 2003). Avoidance of agricultural landscapes and the strong association with sagebrush habitat reinforce the obligate dependence of native shrub-steppe (sagebrush) habitats for sage-grouse populations.

Peripheral sage-grouse populations experienced greater rates of extirpation than core populations. Few extirpations occurred within the core of the species' range; locations greater than $140 \mathrm{~km}$ from peripheral range edge persisted at least $90 \%$ of the time. At minimum, $30 \mathrm{~km}$ range edge was necessary to maintain persistence of sage-grouse (Figs $2 \mathrm{c}$ and 3). Channell \& Lomolino (2000) demonstrated that in many cases (98\% of 245 species examined) species persist in a portion of their peripheral range. Although sage-grouse persistence is strongly associated with core populations, some peripheral populations continue to persist despite their proximity to the edge of the species' range. Such populations may contain unique adaptations to local conditions (Doherty et al., 2003) that could be important for future viability. Two isolated populations in Washington provide an example of persistence in peripheral populations (Schroeder, 1997; Connelly et al., 2004). The northern population (Moses Coulee) exceeded cropland thresholds, while also having lower than expected sagebrush habitat. However, habitat loss may have been mitigated through conversion of cultivated agricultural lands to perennial cover (e.g. Conservation Reserve Program (CRP)) over the last few decades. Therefore, the effect of cultivated crops on sage-grouse persistence may have been confounded by development of CRP acreages. CRP is a US government sponsored program to idle less productive non-irrigated farmland by establishing permanent vegetation. In some areas, CRP fields have provided valuable habitat for sage-grouse (Michael A. Schroeder, unpublished data) but this effect is not uniform across the species' range. Connelly et al. (2004) noted that land enrolled in CRP markedly increased from 1987 to 2004 but that the overall value of these lands to sage-grouse has yet to be demonstrated. Additionally, the density and cover of sagebrush in remaining sagebrush habitats in the northern Washington population may be of sufficient quality to preclude near-term extirpation. However, habitat enhancements, establishment of habitat corridors and reductions in anthropogenic disturbances could enhance the long-term probability of persistence for this population.

Despite our expectation that areas having higher human population growth among census years might best describe sage-grouse extirpations, density of humans in 1950 was the best predictor of extirpation among human population metrics considered ( $\beta_{\text {pop } 1950}=-0.1855$, Table 2$)$. This suggests that stresses to sage-grouse range were well established by the mid-20th century. Accordingly, sage-grouse populations have been declining range-wide since 1965 at a rate of approximately $2 \%$ per year, 
with steeper declines (3.5\% per year) prior to 1986 (Connelly et al., 2004). Of course, sage-grouse declines may have begun prior to 1965 , but most reliable population counts (male attendance at leks) did not begin until 1965 or later. Based on our model predictions, sage-grouse extirpation was more likely in areas having a moderate human population density of at least four people per square kilometre by 1950 (Fig. 2). Sage-grouse populations have been extirpated in virtually all counties reaching a human population density of $c .25$ people per square kilometre by 1950 .

Although we expected road density or distance from roads to be an important factor affecting sage-grouse persistence, neither predicted range-wide patterns in sage-grouse extirpation. We did not consider, however, possible differences associated with intensity of human use of roads (see Lyon \& Anderson, 2003) or the influence of inaccuracies in spatial road data sets. Existing spatial data sets for roads in the western USA are known to be inaccurate, particularly for secondary roads, usually underrepresenting total road densities (Hawbaker \& Radeloff, 2004; Rowland et al., 2006a). Local studies of sage-grouse populations, however, have demonstrated negative direct and indirect effects of roads, affecting both the distribution (Lyon \& Anderson, 2003; Connelly et al., 2004; Holloran \& Anderson, 2005; Aldridge \& Boyce, 2007) and the fitness of individuals (Lyon \& Anderson, 2003; Aldridge \& Boyce, 2007). For instance, sage-grouse no longer occupy leks within $2 \mathrm{~km}$ of Interstate 80 in Wyoming and male attendance at leks within $7.5 \mathrm{~km}$ of Interstate 80 has declined at a greater rate than at leks located between 7.5 and $15 \mathrm{~km}$ from the Interstate (Connelly et al., 2004). However, resolution of historical and current sage-grouse range did not always consider local population loss. The area surrounding Interstate 80 in Wyoming is still considered extant range, despite documented losses. Accurate assessments of road impacts to sage-grouse populations are likely to be more relevant to assessment of effects on local population analyses, such as status and trends of individual leks.

Sage-grouse populations are affected by precipitation and drought (June, 1963). Drought conditions result in decreased nest success (Holloran et al., 2005) and/or reduced chick survival (Aldridge, 2005). We found that the number of severe droughts from 1950 to 2003 had a weak negative effect on patterns of sage-grouse persistence. Droughts, however, may have a greater influence on future sage-grouse populations, as temperatures are projected to increase over the next 50 years (Neilson et al., 2005), resulting in drier conditions and reduced sagebrush habitat quality. Not only will habitat quality decline with warmer and drier conditions, but climate change (drier conditions) also has the potential to influence impacts caused by livestock grazing (Connelly et al., 2000), invasions of non-native species and change fire frequency (Connelly et al., 2000, 2004). While seasonal precipitation patterns cannot be changed, livestock grazing practices could be altered in dry years to reduce the removal of herbaceous vegetation. Climate change has been demonstrated to enhance non-native plant invasions (Smith et al., 2000; Bradley \& Mustard, 2006; Chambers et al., 2007) and dramatically alter fire frequencies (Westerling et al., 2006). Management strategies that reduce fire frequency should be considered, because fire has been shown to reduce the quality of sagebrush habitats resulting in sage-grouse population declines (Connelly et al., 2000; Byrne, 2002; Pederson et al., 2003). Given the uncertainties associated with the impact of climate change on sagebrush habitats, as well as increased energy extraction activities in sagebrush ecosystems, management actions that increase and enhance the number, quality and connectivity of sagebrush habitats, while limiting fragmentation from anthropogenic sources (see Aldridge \& Boyce, 2007), will be particularly important for maintaining viable sage-grouse populations.

We suggest that model predictions could be used as an initial conservation tool. While misclassification of sage-grouse persistence could be due to inaccuracies in the current range maps (Schroeder et al., 2004) or other environmental and anthropogenic factors not considered, we recommend using model outputs to spatially identify two conservation practices: (1) mitigation of negative effects in areas where populations are most at risk, and (2) identification of areas best suited for possible recolonization. Areas currently occupied by sage-grouse but predicted as extirpated (i.e. false-negative predictions, Fig. 4) can be used to rank populations most at risk of future extirpation and subsequently identify sites for immediate conservation efforts. Conversely, extirpated range most similar to habitats currently occupied by sage-grouse (i.e. false-positive predictions, Fig. 4) can be used to identify areas most suitable for recolonization. Establishing connectivity to core populations or increasing patch size through restoration efforts, together with possible reintroduction programmes, may provide a strategy for reversing historical sage-grouse population declines.

\section{CONCLUSION}

We used a digital range map depicting the current and estimated presettlement distribution for sage-grouse (Schroeder et al., 2004) to determine whether common, landscape factors can be used to predict range-wide patterns of sage-grouse extirpation. Factors contributing to range-wide persistence of sage-grouse included, agricultural cultivation, amount of sagebrush habitat, prevalence of droughts, periphery of range, and human density in 1950. Although we highlight populations that may be at risk based on past patterns of extirpation, future range loss may relate less to historical mechanisms and more to recent changes in land use and habitat condition, including energy developments (Aldridge \& Boyce, 2007; Walker et al., 2007), non-native species invasions (Bradley \& Mustard, 2006; Bergquist et al., 2007) and spread of new invasive disease such as West Nile virus (Naugle et al., 2004).

Conservation of remaining sage-grouse range will likely require prioritization of populations. Maps predicting probability of sage-grouse persistence could be used in conjunction with local measures of population performance and known threats to prioritize or 'triage' sites (Wisdom et al., 2005b) for management and protection. Conservation efforts should begin by maintaining large expanses of sagebrush habitat and enhancing the quality and connectivity of those patches. If sage-grouse are protected under the US Endangered Species Act, retrospective assessments 
of sage-grouse range and population performance will be critical to understanding relationships between anthropogenic drivers of landscape change and sage-grouse population persistence.

\section{ACKNOWLEDGEMENTS}

This research was supported by the US Geological Survey, Colorado State University, and the University of Alberta. We thank D.J. Saher, D.J. Neubaum, S.S. Germaine, and C.P. Melcher, for reviewing previous drafts of this manuscript. A.T. Peterson, C.A. Hagen, and V.C. Radeloff provided useful reviews.

\section{REFERENCES}

Aldridge, C.L. (2005) Habitats for persistence of greater sage-grouse (Centrocercus urophasianus) in Alberta, Canada. PhD Thesis, University of Alberta, Edmonton, Alberta, Canada.

Aldridge, C.L. \& Boyce, M.S. (2007) Linking occurrence and fitness to persistence: a habitat-based approach for greater sage-grouse. Ecological Applications, 17, 508-526.

Aldridge, C.L. \& Brigham, R.M. (2003) Distribution, abundance, and status of the greater sage-grouse, Centrocercus urophasianus, in Canada. Canadian Field-Naturalist, 117, 25-34.

Beck, J.L. \& Mitchell, D.L. (2000) Influences of livestock grazing on sage grouse habitat. Wildlife Society Bulletin, 28, 9931002.

Bergquist, E., Evangelista, P., Stohlgren, T.J. \& Alley, N. (2007) Invasive species and coal bed methane development in the Powder River Basin, Wyoming. Environmental Monitoring and Assessment, 128, 381-394.

Bradley, B.A. \& Mustard, J.F. (2006) Characterizing the landscape dynamics of an invasive plant and risk of invasion using remote sensing. Ecological Applications, 16, 1132-1147.

Braun, C.E. (1998) Sage grouse declines in western North America: what are the problems? Proceedings of the Western Association of State Fish and Wildlife Agencies, 78, 139-156.

Braun, C.E., Baker, M.F., Eng, R.L., Gashwiler, J.S. \& Schroeder, M.H. (1976) Conservation committee report on effects of alteration of sagebrush communities on the associated avifauna. Wilson Bulletin, 88, 165-171.

Braun, C.E., Oedekoven, O.O. \& Aldridge, C.L. (2002) Oil and gas development in western North America: effects on sagebrush steppe avifauna with particular emphasis on sage grouse. Transactions of the North American Wildlife and Natural Resources Conference, 67, 337-349.

Byrne, M.W. (2002) Habitat use by female greater sage grouse in relation to fire at Hart Mountain National Antelope Refuge, Oregon. MSc Thesis, Oregon State University, Corvallis, Oregon. Chambers, J.C., Roundy, B.A., Blank, R.R., Meyer, S.E. \& Whittaker, A. (2007) What makes Great Basin sagebrush ecosystems invasible by Bromus tectorum? Ecological Monographs, 77, 117-145.

Channell, R. \& Lomolino, M.V. (2000) Dynamic biogeography and conservation of endangered species. Nature, 403, 84-86.

Chatterjee, S., Hadi, A.S. \& Price, B. (2000) Regression analysis by example. John Wiley and Sons, New York, New York.
Comer, P., Kagan, J., Heiner, M. \& Tobalske, C. (2002) Current distribution of sagebrush and associated vegetation in the western United States. Map 1 : 200,000 scale. USGS Forest and Rangeland Ecosystems. Science Center, Boise, Idaho, and The Nature Conservancy, Boulder, Colorado. URL: http:// sagemap.wr.usgs.gov/images/sage1.jpg.

Connelly, J.W. \& Braun, C.E. (1997) Long-term changes in sage grouse Centrocercus urophasianus populations in western North America. Wildlife Biology, 3, 229-234.

Connelly, J.W., Reese, K.P., Fischer, R.A. \& Wakkinen, W.L. (2000) Response of sage grouse breeding population to fire in southeastern Idaho. Wildlife Society Bulletin, 28, 90-96.

Connelly, J.W., Knick, S.T., Schroeder, M.A. \& Stiver, S.J. (2004) Conservation assessment of greater sage-grouse and sagebrush habitats. Western Association of Fish and Wildlife Agencies, Cheyenne, Wyoming.

Crawford, J.A., Olson, R.A., West, N.E., Mosley, J.C., Schroeder, M.A., Whitson, T.D., Miller, R.F., Gregg, M.A. \& Boyd, C.S. (2004) Synthesis paper - ecology and management of sagegrouse and sage-grouse habitat. Journal of Range Management, 57, 2-19.

Diniz, J.A.F., -Filho, Bini, L.M. \& Hawkins, B.A. (2003) Spatial autocorrelation and red herrings in geographical ecology. Global Ecology and Biogeography, 12, 53-64.

Doherty, P.F., Jr Boulinier, T. \& Nichols, J.D. (2003) Local extinction rates at the edge and interior of species' ranges. Annales Zoologici Fennici, 40, 145-153.

Fielding, A.H. \& Bell, J.F. (1997) A review of methods for the assessment of prediction errors in conservation presence/ absence models. Environmental Conservation, 24, 38-49.

Hagen, C.A., Connelly, J.W. \& Schroeder, M.A. (2007) A metaanalysis of greater sage-grouse Centrocercus urophasianus nesting and brood-rearing habitats. Wildlife Biology, 13 (Suppl. 1), 43-50.

Hawbaker, T.J. \& Radeloff, V.C. (2004) Roads and landscape pattern in northern Wisconsin based on a comparison of four road data sources. Conservation Biology, 18, 1233-1244.

Hayes, G.F. \& Holl, K.D. (2003) Cattle grazing impacts on annual forbs and vegetation composition of mesic grasslands in California. Conservation Biology, 17, 1694-1702.

Holechek, J.L., Pieper, R.D. \& Herbel, C.H. (2001) Range management: principles and practices. Prentice Hall, Inc, Toronto, Canada.

Holloran, M.J. \& Anderson, S.H. (2005) Greater sage-grouse population response to natural gas development in Western Wyoming: are regional populations affected by relatively localized disturbances? Transactions of the North American Wildlife and Natural Resources Conference, 70, 16-170.

Holloran, M.J., Heath, B.J., Lyon, A.G., Slater, S.J., Kuipers, J.L. \& Anderson, S.H. (2005) Greater sage-grouse nesting habitat selection and success in Wyoming. Journal of Wildlife Management, 69, 638-649.

Hosmer, D.W. \& Lemeshow, S. (2000) Applied logistic regression. John Wiley \& Sons, Inc., New York.

June, J.W. (1963) Wyoming sage grouse population measurement. Proceedings of the Western Association of State Game and Fish Commissioners, 43, 206-211. 
Knick, S.T., Dobkin, D.S., Rotenberry, J.T., Schroeder, M.A., Vander Haegen, M.A. \& Van Riper, C. (2003) Teetering on the edge or too late? Conservation and research issues for avifauna of sagebrush habitats. Condor, 105, 611-634.

Lennon, J.J. (2000) Red-shifts and red herrings in geographical ecology. Ecography, 23, 101-113.

Leonard, K.M., Reese, K.P. \& Connelly, J.W. (2000) Distribution, movements and habitats of sage grouse Centrocercus urophasianus on the upper Snake River Plain of Idaho: changes from the 1950s to the 1990s. Wildlife Biology, 6, 265-270.

Liu, C., Berry, P.M., Dawson, T.P. \& Pearson, R.G. (2005) Selecting thresholds of occurrence in the prediction of species distributions. Ecography, 28, 385-393.

Lyon, A.G. \& Anderson, S.H. (2003) Potential gas development impacts on sage grouse nest initiation and movement. Wildlife Society Bulletin, 31, 486-491.

Manel, S., Williams, H.C. \& Ormerod, S.J. (2001) Evaluating presence-absence models in ecology: the need to account for prevalence. Journal of Applied Ecology, 38, 921-931.

Menard, S. (1995) Applied logistic regression analysis. Sage Publications Inc., Thousand Oaks, California.

Naugle, D.E., Aldridge, C.L., Walker, B.L., Cornish, T.E., Moynahan, B.J., Holloran, M.J., Brown, K., Johnson, G.D., Schmidtman, E.T., Mayer, R.T., Kato, C.Y., Matchett, M.R., Christiansen, T.J., Cook, W.E., Creekmore, T., Falise, R.D., Rinkes, E.T. \& Boyce, M.S. (2004) West nile virus: pending crisis for greater sage-grouse. Ecology Letters, 7, 704-713.

Neilson, R.P., Lenihan, J.M., Bachet, D. \& Drapek, R.J. (2005) Climate change implications for sagebrush ecosystems. Transactions of the North American Wildife and Natural Resources Conference, 70, 145-159.

Nielsen, S.E., Munro, R.H.M., Bainbridge, E.L., Stenhouse, G.B. \& Boyce, M.S. (2004) Grizzly bears and forestry II. Distribution of grizzly bear foods in clearcuts of westcentral Alberta, Canada. Forest Ecology and Management, 199, 67-82.

Paige, C. \& Ritter, S.A. (1999) Birds in a Sagebrush Sea: managing sagebrush habitats for bird communities. Partners in Flight Western Working Group, Boise, Idaho.

Patterson, R.L. (1952) The sage grouse in Wyoming. Sage Books, Inc., Denver, Colorado.

Pederson, E.K., Connelly, J.W., Hendrickson, J. \& Grant, W.E. (2003) Effect of sheep grazing and fire on sage grouse populations in southeastern Idaho. Ecological Modelling, 165, 23-47.

Rowland, M.M., Leu, M., Hanser, S., Finn, S.P., Aldridge, C.L., Knick, S.T., Suring, L.H., Boyd, J.M., Wisdom, M.J. \& Meinke, C.W. (2006a) Assessment of threats to sagebrush habitats and associated species of concern in the Wyoming Basins. Version 2.0 March 2006. Unpublished report on file at USGS Biological Resources Discipline, Snake River Field Station, 970 Lusk St, Boise, ID 83706.

Rowland, M.M., Wisdom, M.J., Suring, L.H. \& Meinke, C.W. (2006b) Greater sage-grouse as an umbrella species for sagebrushassociated vertebrates. Biological Conservation, 129, 323-335.

Schroeder, M.A. (1997) Unusually high reproductive effort by sage grouse in a fragmented habitat in north-central Washington. Condor, 99, 933-941.

Schroeder, M.A., Young, J.R. \& Braun, C.E. (1999) Sage grouse (Centrocercus urophasianus). The Birds of North America, Number 28 (ed. by A. Pool and F. Gill). The Birds of North America, Inc., Philadelphia, Pennsylvania.

Schroeder, M.A., Aldridge, C.L., Apa, A.D., Bohne, J.R., Braun, C.E., Bunnell, S.D., Connelly, J.W., Deibert, P.A., Gardner, S.C., Hilliard, M.A., Kobriger, G.D., McAdam, S.C., McCarthy, C.W., McCarthy, J.J., Mitchell, D.L., Rickerson, E.V. \& Stiver, S.J. (2004) Distribution of sage-grouse in North America. Condor, 106, 363-376.

Smith, S.D., Huxman, T.E., Zitzer, S.F., Charlet, T.N., Housman, D.C., Coleman, J.S., Fenstermaker, L.K., Seemann, J.R. \& Nowak, R.S. (2000) Elevated $\mathrm{CO}_{2}$ increases productivity and invasive species success in an arid ecosystem. Nature, 408, 79-82.

Swenson, J.E., Simmons, C.A. \& Eustace, C.D. (1987) Decrease of sage grouse Centrocercus urophasianus after ploughing of sagebrush steppe. Biological Conservation, 41, 125-132.

Swets, J.A. (1988) Measuring the accuracy of diagnostic systems. Science, 240, 1285-1293.

Walker, B.L., Naugle, D.E. \& Doherty, K.E. (2007) Sage-grouse populations and energy development. Journal of Wildlife Management, 71, 2644-2654.

Westerling, A.L., Hidalgo, H.G., Cayan, D.R. \& Swetnam, T.W. (2006) Warming and earlier spring increase. Western US forest wildfire activity. Science, 313, 940-943.

White, H. (1982) Maximum likelihood estimation of misspecified models. Econometrika, 50, 1-26.

Wisdom, M.J., Rowland, M.M., Wales, B.C., Hemstrom, M.A., Hann, W.J., Raphael, M.G., Holthausen, R.S., Gravenmier, R.A. \& Rich, T.D. (2002a) Modeled effects of sagebrush-steppe restoration on greater sage-grouse in the Interior Columbia Basin, USA. Conservation Biology, 16, 1223-1231.

Wisdom, M.J., Wales, B.C., Rowland, M.M., Raphael, M.G., Holthausen, R.S., Rich, T.D. \& Saab, V.A. (2002b) Performance of greater sage-grouse models for conservation assessment in the Interior Columbia Basin, USA. Conservation Biology, 16, 1232-1242.

Wisdom M.J., Rowland M.M. \& Suring, L.H. eds (2005a) Habitat threats in the sagebrush ecosystem: methods of regional assessment and applications in the Great Basin. Alliance Communication Group, Lawrence, Kansas.

Wisdom, M.J., Rowland, M.M. \& Tausch, R.J. (2005b) Effective management strategies for sage-grouse and sagebrush: a question of triage? Transactions of the North American Wildlife and Natural Resources Conference, 70, 145-159.

Editor: Mark Robertson 